\title{
POLYMORPHISM OF THE GLYCEROL-3-PHOSPHATE OXIDASE GENE AS ONE OF THE MYCOPLASMA PNEUMONIAE GENETIC FEATURES INFLUENCING THE FORMATION OF PATHOGENICITY FACTORS
}

\author{
C SVETLANA A. KOSTIUK, TATYANA V. HLINKINA, OLGA S. POLUYAN, \\ TATYANA V. RUDENKOVA
}

Belarusian Medical Academy of Postgraduate Education, Minsk, Republic of Belarus

\begin{abstract}
Objective: to identify possible genetic variants of Mycoplasma pneumoniae in a glycerol-3-phosphate oxidase gene fragment corresponding to the FAD binding domain of the enzyme, and to study their pathogenic properties.

Material and methods: The material for the obtainment of Mycoplasma pneumoniae isolates was sputum, epithelial cell scrapings from the nasopharynx, tracheobronchial secretion from 85 children and adolescents diagnosed with bronchitis and pneumonia and detecting Mycoplasma pneumoniae DNA. The isolation of Mycoplasma pneumoniae from the clinical material was proceeded in a mycoplasma medium without an energy source. The DNA isolation from the biological material and from the culture fluid was performed by the method of sorption extraction. The sediment of the cellular elements of the sputum was used for the DNA extraction with the use of the CTAB reagent.

Results. Synonymous and non-synonymous nucleotide substitutions have been identified in 54 clinical isolates of Mycoplasma pneumoniae. It has been found that the amino acid substitutions His51Leu and Asp55His are essential for the realization of the pathogenic potential of the Mycoplasma pneumoniae isolates associated with the production of hydrogen peroxide.

Conclusion. The A152T (His51Leu) and G163C (Asp55His) substitutions were identified in the G3P oxidase gene of the Mycoplasma pneumonia clinical isolates, and their presence was associated with the variability in the activity of the enzyme. The Mycoplasma pneumoniae isolates carrying the A152T substitution (His51Leu) produced hydrogen peroxide in significantly lower amounts $(5 \mathrm{mg} / 1)$ in comparison with the reference strain $(10 \mathrm{mg} / 1)$ and had reduced cytotoxicity in relation to respiratory epithelial cells. The Mycoplasma pneumoniae isolates carrying the substitution G163C (Asp55His) were characterized by enhanced pathogenic properties, such as increased production of hydrogen peroxide $(25 \mathrm{mg} / \mathrm{l})$ and more pronounced cytotoxicity towards respiratory epithelial cells.
\end{abstract}

Key words: Mycoplasma pneumoniae, glycerol-3-phosphate oxidase, hydrogen peroxide, nucleotide substitutions, cytotoxicity.

\section{FOR CITATION:}

Kostiuk SA, Hlinkina TV, Poluyan OS, Rudenkova TV. Polymorphism of the glycerol-3-phosphate oxidase gene as one of the Mycoplasma Pneumoniae genetic features influencing the formation of pathogenicity factors. Problems of Health and Ecology=Problemy Zdorov'ya i Ekologii. 2020;64(2):130-135. (In Russ.)

\section{ПОАИМОРФИЗМ ГЕНА ГАИЦЕРОА-З-ФОСФАТ ОКСИДАЗЫ КАК ОДИН ИЗ ГЕНЕТИЧЕСКИХ ФАКТОРОВ ПАТОГЕННОСТИ MYCOPLASMA PNEUMONIAE}

\author{
(C) С.А. КОСТЮК, Т.В. ГАИНКИНА, О.С. ПОАУЯН Т.В. РУДЕНКОВА
}

ГУО “Беморусская медицинская академия посмедипмомного образования", г. Минск, Респубцика Бемарусь

\section{PEЗ ЮME}

Цель: выявить возможные генетические варианты Mycoplasma pneumoniae по фрагменту гена глицерол-3фосфат оксидазы, соответствующему ФАД связывающему домену фермента, и изучить их патогенные свойства.

материалы и методы. Материалом дия получения изолятов Mycoplasma pпeuтопіае стали мокрота, соскобы эпитемиальных клеток из носоглотки, трахеобронхиальный секрет 85 детей и подростков с диагнозами бронхит и пневмония, у которых была выявлена ДНК Mycoplasma pneumoniae. Выделение Mycoplasma pneumoniae из клинического материала проводими с использованием среды для микоплазм без источника энергии. Выдемение ДНК из биологического материала пациентов и кумьтурамьной жидкости проводими методом сорбционной экстракции. Осадок клеточных элементов мокроты использовали для выделения ДНК с применением ЦТАБ реактива.

Резулътаты. В 54 клинических изолятах Mycoplasma pneumoniae выявлены синонимичные и несинонимичные нуклеотидные замены. Установлено, что аминокислотные замены His51Leu и Asp55His являются значимыми для реализации патогенного потенциала изолятов Mycoplasma pneumoniae, связанного с продукцией пероксида водорода.

Заключение. В гене ГЗФ оксидазы клинических изолятов Mycoplasma pneumoniae выявлены замены A152T (His51Leu) и G163C (Asp55His), наличие которых сопровождалось вариабельностью активности фермента. Изоляты Mycoplasma pneumoniae, несущие замену A152T (His51Leu), продуцировали пероксид водорода значимо ниже $(5 \mathrm{m \Gamma} / \Lambda)$ уровня продукции референсным штаммом $(10 \mathrm{mг} / \Lambda)$ и проявляли сниженную цитотоксичность по отношению к клеткам респираторного эпителия, тогда как изоляты Mycoplasma pneumoniae, несущие замену G163C (Asp55His), характеризовались усиленным патогенными свойствами, что проявлялось в повышенной про-

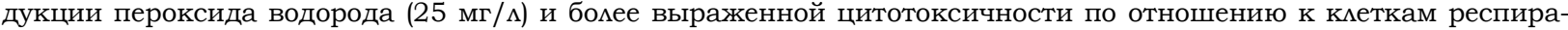
торного эпителия. 
ключевые слова: Mycoplasma pпеитопіае, глииерол-3-фосфрат оксидаза, пероксид водорода, нуклеотидные замены, иитотоксичность.

ДАЯ цитИРОВАния:

Костюк СА, ГАинкина ТВ, Полуян ОС, Руденкова ТВ. Полиморфизм гена глицерол-3-фосфат оксидазы как один из генетических факторов патогенности Mycoplasma pneumoniae. Проблемы Здоровья и Экологии. 2020;64(2):130-135.

\section{Introduction}

Mycoplasma pneumoniae infects the human respiratory tract and is an etiological factor of various nosological forms of respiratory pathology: sinusitis, pharyngitis, laryngitis, bronchitis, pneumonia, bronchial asthma [1]. The distinguishing features of the pathogen include the small genome, the absence of the cell wall and limited metabolic possibilities, as with gram-positive streptococci from which mycoplasma originated, Mycoplasma pneumoniae lacks such metabolic pathways as the tricarboxylic acid cycle and the electron transport chain with cytochromes. Therefore, glycolysis is of primary importance for the pathogen in terms of the provision of energy resources [2]. This metabolic pathway is closely related to the pathogenicity of $M y$ coplasma pneumoniae, since during the glycolysis reactions hydrogen peroxide is released, which, in addition to its bactericidal action, has a cytopathic effect on the cells of the respiratory tract [3].

Hydrogen peroxide is a universal pathogenetic marker secreted by Mycoplasma pneumoniae during the reaction of the conversion of glycerol to dihydroxyacetonephosphate. This reaction is catalyzed by the enzyme glycerol-3-phosphate (G3P) oxidase (EC 1.1.3.21) [4]. The presence of G3P oxidase is a distinctive feature of $\mathrm{Myco}-$ plasma pneumoniae, since most microorganisms have G3P dehydrogenase (EC 1.1.1.8), reacting with which electrons pass to nicotinamide adenine dinucleotide (NAD) and hydrogen peroxide is not formed. Mycoplasma pneumoniae G3P oxidase reduces molecular oxygen to hydrogen peroxide. This process is an important factor for the determination of the cytotoxic properties of the pathogen [5].

Mycoplasma infection is characterized by variable course patterns ranging from mild forms to severe pathologies [6]. The heterogeneity of the Mycoplasma pneumoniae G3P oxidase gene can cause different levels of hydrogen peroxide production and, as a result, clinical variants of mycoplasma infection will develop. At present, Mycoplasma pneumoniae G3P oxidase is likely to be a possible ther- apeutic target [7], but little is known about the structural features of the Mycoplasma pneumoniae enzyme gene recovered from the biological material of patients with respiratory pathology, as well as about the features of the production of hydrogen peroxide by the clinical isolates of Mycoplasma pneumoniae. Mycoplasma pneumoniae G3P oxidase includes flavin adenine dinucleotide (FAD) binding domain and substrate binding domain, the FAD binding domain being involved in proton transfer with the formation of hydrogen peroxide [8]. Therefore, the study of the Mycoplasma pneumoniae oxidase gene fragment corresponding to this domain proves relevant.

\section{Objective}

To identify possible genetic variants of Mycoplasma pneumoniae in the glycerol-3phosphate oxidase gene fragment corresponding to the FAD binding domain of the enzyme, and to study their pathogenic properties.

\section{Materials and methods}

Acquisition of the clinical isolates of $\mathrm{My}$ coplasma pneumoniae. The material for the obtainment of Mycoplasma pneumoniae was sputum, epithelial cell scrapings from the nasopharynx (hereinafter referred to as scrapings), tracheobronchial secretion of 85 children and adolescents diagnosed with bronchitis and pneumonia (from 0 to 15 years) and detecting Mycoplasma pneumoniae DNA.

To isolate Mycoplasma pneumoniae from the clinical material, a $100 \mu \mathrm{l}$ sample of the biological material was placed in $1 \mathrm{ml}$ of a mycoplasma medium (broth with mycoplasma additive, Thermo Scientific. Oxoid), but without an energy source, i.e. glucose, and with antibacterial agents (penicillin and talia acetate) to inhibit the growth of the concomitant microflora. Cultures were kept for $30 \mathrm{~min}$ at room temperature, then carried over to the culture medium with the glucose additive and incubated for $2-3$ weeks at $37{ }^{\circ} \mathrm{C}$ in a humidified environment with $5 \% \mathrm{CO}_{2}$. The pathogen growth was assessed by two methods: visually by the color of the $\mathrm{pH}$ indicator of the nutrient medium changing from red to yellow and using 
the RT PCR method (LightMix Mycoplasma pneumoniae kit, TIB MOLBIOL GmbH, Germany). Mycoplasma pneumoniae ATCC 15531 was used as a reference strain.

Study of Mycoplasma pneumoniae G3P oxidase gene polymorphism. The DNA isolation from the biological material of the patients (scraping, tracheobronchial secretion) and from the culture fluid was performed by the method of sorption extraction (sets QIAamp DNA Mini, Qiagen, Germany and RealBest DNA Extraction 1, JSC VECTORBEST, Russian Federation). The sediment of the cellular elements of the sputum was used for the DNA extraction with the use of a CTAB reagent [9].

The DNA isolated from the 54 clinical isolates of Mycoplasma pneumoniae, that of the reference strain of Mycoplasma pneumoniae and of the biological material was exposed to amplification using synthesized primer pairs ("Primetekh", Belarus) selected on the basis of the gene structure of Mycoplasma pneumoniae G3P oxidase (MPN051, GeneBank number NC_000912.1, region 63494 ... 64648):

MPN051-forward -

5 -40-ATAGGCTGTGCCACTGCTTA-59-3`

MPN051- reverse -

5'-700-ACTGACCTCGACGGGTTGT-682-3`

according to the program of $95{ }^{\circ} \mathrm{C}$ for 5 minutes, 45 cycles of $95{ }^{\circ} \mathrm{C}$ for $60 \mathrm{~s}, 58{ }^{\circ} \mathrm{C}$ for $60 \mathrm{~s}, 72{ }^{\circ} \mathrm{C}$ for $60 \mathrm{~s}, 1$ cycle of $72{ }^{\circ} \mathrm{C}$ for $10 \mathrm{~min}$. The expected size of the PCR product was $660 \mathrm{bp}$.

The nucleotide sequence of the obtained G3P gene fragment of Mycoplasma pneumoniae oxidase was studied using the Sanger sequencing PCR method. Studies were performed using the BigDye Terminator Cycle Sequencing v3.1 reagent kit (Applied Biosystems, USA). The acquired fragments were separated by capillary polyacrylamide gel electrophoresis in the ABI Prism 310 genetic analyzer (Applied Biosystems, USA). Data on the nucleotide sequence of the samples were examined using the nucleotide-nucleotide BLAST search system (www.ncbi. nlm.nlm.nih.gov/blast/bl2seq/bl2.html) to identify the sequence correspondence to the reference gene. The nucleotide sequence of the reference gene was obtained from the GenBank database and is represented by the Mycoplasma pneumoniae gene MPN051 (NC_000912.1, region 63494 ... 64648).

In vivo estimation of hydrogen peroxide production. The estimation of hydrogen peroxide production was performed by the clinical isolates and reference strain of $\mathrm{Myco}^{-}$ plasma pneumoniae. For this purpose, bacte- ria grown in the mycoplasma medium were resuspended in a phosphate-buffered saline to obtain suspension of Mycoplasma pneumoniae with an optical density of $1 \mathrm{AU}$ at a wavelength of $550 \mathrm{~nm}(\mathrm{OD} 550=1)$. Glycerol was added to $1 \mathrm{ml}$ of the obtained Mycoplasma pneumoniae suspensions. The final concentration of glycerol was $100 \mu \mathrm{mol} / 1$, which corresponds to its concentration in the blood serum [10].

The aliquots of the Mycoplasma pneumoniae suspensions free of glycerol served as control ones. The production of hydrogen peroxide was evaluated colorimetrically after 20 minutes using test strips of the Merckoquant peroxide test (Merck, Germany). The test strips were immersed in the suspensions of Mycoplasma pneumoniae for 1 sec. The amount of hydrogen peroxide was judged by the changing color of the test strips. The measurement range of hydrogen peroxide was $0.5-25 \mathrm{mg} / 1$.

Evaluation of cytotoxicity of Mycoplasma pneumoniae in cell culture. The human lung carcinoma cell line A549 was used as an in vitro model. Source: American Type Culture Collection ATCC (CCL-185). Cells were seeded in 24-spot plates at a concentration of $5 \times 105$ cells per spot and incubated for 24 hours at $37{ }^{\circ} \mathrm{C}$ in a humidified atmosphere with $5 \%$ $\mathrm{CO}_{2}$ to achieve $100 \%$ confluency. To assess cytotoxicity of the clinical isolates and Mycoplasma pneumoniae reference strain, the confluent A549 cells were infected with Mycoplasma pneumoniae suspensions conforming to MacFarland standard 2 U. In 24, 48 and 72 hours, the cytotoxicity under the action of Mycoplasma pneumoniae was evaluated in a trypan blue test. The cytotoxicity test was performed in triplets to assess the reproducibility of the test results.

\section{Results and discussion}

In the course of the genetic analysis of the structure of the G3P oxidase gene fragment corresponding to the FAD binding domain, synonymous and non-synonymous nucleotide substitutions were identified in the 54 clinical isolates of Mycoplasma pneumoniae (see Table 1).

The obtained data corresponded to the results of direct DNA sequencing of the pathogen when isolated directly from the biological material avoiding the stage of in vitro cultivation, which makes it possible to exclude the influence of the cultivation process on the probability of the formation of identified nucleotide substitutions in the Mycoplasma pneumoniae G3P oxidase. 
Table 1 - Genetic analysis of the Mycoplasma pneumoniae G3P oxidase gene sequence

\begin{tabular}{|l|c|c|c|c|c|c|c|c|}
\hline \multirow{2}{*}{ Sample No. } & \multicolumn{6}{|c|}{ Position in Gene MPN051 } & \multirow{2}{*}{$\begin{array}{c}\text { Change in the } \\
\text { polypeptide chain }\end{array}$} & $\begin{array}{c}\text { Hydrogen peroxide } \\
\text { production(mg/l) }\end{array}$ \\
\cline { 2 - 7 } & 99 & 152 & 163 & 181 & 391 & 432 & His51Leu & 5 \\
\hline 3 & - & $\mathrm{A} \rightarrow \mathrm{T}$ & - & - & $\mathrm{T} \rightarrow \mathrm{C}$ & - & - & 10 \\
\hline 17 & $\mathrm{~A} \rightarrow \mathrm{G}$ & - & - & - & - & $\mathrm{A} \rightarrow \mathrm{G}$ & His51Leu & 5 \\
\hline 26,33 & - & $\mathrm{A} \rightarrow \mathrm{T}$ & - & - & - & - & Asp55His & 25 \\
\hline $29,46,50$ & - & - & $\mathrm{G} \rightarrow \mathrm{C}$ & - & - & - & - & 10 \\
\hline 35 & $\mathrm{~A} \rightarrow \mathrm{G}$ & - & - & - & - & - & Leu61Val & 10 \\
\hline 39 & - & - & - & $\mathrm{T} \rightarrow \mathrm{G}$ & - & - & Asp55His & 25 \\
\hline 41 & $\mathrm{~A} \rightarrow \mathrm{G}$ & - & $\mathrm{G} \rightarrow \mathrm{C}$ & - & - & - & \\
\hline
\end{tabular}

In the reference strain and in the clinical isolates of Mycoplasma pneumoniae 1-2, 4-16, 18-25, 27, 28, 30-32, 34, 36$38,40,42-54$, no nucleotide substitutions were identified in the tested fragment of G3P oxidase gene

Table 1 suggests that for Mycoplasma pneumoniae isolates with synonymous nucleotide substitutions A99G, T391C and A432G and non-synonymous nucleotide substitution $\mathrm{T} 181 \mathrm{G}$, the level of hydrogen peroxide production was $10 \mathrm{mg} / 1$, which corresponded to the value of this indicator for Mycoplasma pneumoniae isolates, which did not show any nucleotide substitutions, including the reference strain of Mycoplasma pneumonia. In turn, two non-synonymous substitutions: A152T (His51Leu) and G163C (Asp55His), identified in the G3P oxidase gene of the clinical isolates of Mycoplasma pneumoniae, were associated with low (5 mg/l) and high (25 $\mathrm{mg} / 1)$ levels of hydrogen peroxide production, respectively.

The amino acid substitutions His51Leu and Asp55His may be significant for the realization of the pathogenic potential of the $M y$ coplasma pneumoniae isolates associated with the production of hydrogen peroxide.

Hydrogen peroxide is formed as a result of the reaction catalyzed by G3P oxidase: $\mathrm{O}_{2}+$ phosphate- $\mathrm{C} 1 \mathrm{H}_{2}-\mathrm{C} 2 \mathrm{H}(\mathrm{OH})-$ $\mathrm{C} 3 \mathrm{H}_{2}(\mathrm{OH}) \rightarrow$ phosphate- $\mathrm{C} 1 \mathrm{H}_{2}-\mathrm{C} 2(\mathrm{O})-$ $\mathrm{C}_{3} \mathrm{H}_{2}(\mathrm{OH})+\mathrm{H}_{2} \mathrm{O}_{2}$

His in position 51 of the G3P oxidase polypeptide chain is essential for the formation of hydrogen peroxide: the proton atom from the C2 substrate atom (glycerol-3phosphate) is transferred to the nitrogen atom of the histidine imidazole ring, then to the N5 FAD atom and then to the final acceptor, i.e. molecular oxygen, resulting in the formation of hydrogen peroxide [8]. His51Leu replacement can slow down or even interrupt the reaction of hydrogen peroxide formation, since Leu does not contain a nitrogen atom capable of accepting a proton. The clinical isolates of Mycoplasma pneumoniae with the nucleotide substitution A152T, leading to the replacement of
His51Leu, were characterized by low pathogenic properties, resulting in the decreased production of hydrogen peroxide: $5 \mathrm{mg} / 1 \mathrm{com}-$ pared to the test findings of the evaluation of the production of hydrogen peroxide with the help of the isolates of Mycoplasma pneumoniae without nucleotide substitutions $(10 \mathrm{mg} / \mathrm{l})$.

The high level of hydrogen peroxide production $(25 \mathrm{mg} / \mathrm{l})$ revealed in 4 isolates of Mycoplasma pneumoniae with G163C substitution (Asp55His) may be due to the fact that His55 appearing near His51 as a result of substitution takes on the function of an additional proton transporter to form the hydrogen peroxide molecule. Increased production of hydrogen peroxide by the isolates of $\mathrm{Myco}-$ plasma pneumoniae with the G163C (Asp55His) substitution can be considered as enhanced pathogenic properties of the microorganism as a result of the appearance of nucleotide substitution.

The metabolism of Mycoplasma pneumoniae glycerol leads to the production of hydrogen peroxide - one of the main factors of the pathogenicity of the microorganism, which has a cytotoxic effect on the cells of the respiratory epithelium.

To assess the cytotoxicity of Mycoplasma pneumoniae clinical isolates, A549 cells were infected with Mycoplasma pneumoniae cultures. Cell line A549 has all the characteristic features of type 2 alveolar cells and is widely used to evaluate the effect of various infectious agents on the respiratory epithelium [10]. The infection of the A549 cells with Mycoplasma pneumoniae was confirmed in 24, 48 and 72 hours by the PCR detection of the microorganism's DNA, no DNA of Mycoplasma pneumoniae being detected in the control cells. The revealed signs of the cytopathic effect of Mycoplasma pneumoniae on A549 cells included breaks in cell monolay- 
ers, cell rounding, an increased size of the nuclei and vacuolization of the cytoplasm.

The clinical isolates of Mycoplasma pneumoniae producing hydrogen peroxide along with the reference strain of Mycoplasma pneumoniae $(10 \mathrm{mg} / \mathrm{l})$ caused almost complete lysis of A549 cells by the third day of infection ( $85 \%$ cytotoxicity, see Table 2 ).

Table 2 - Cytotoxicity (\%) of Mycoplasma pneumoniae with different levels of hydrogen peroxide production, $\mathrm{Me}\left[\mathrm{Q}_{25} ; \mathrm{Q}_{75}\right]$

\begin{tabular}{|c|c|c|c|}
\hline \multirow{2}{*}{ Incubation time } & \multicolumn{3}{|c|}{ Production of hydrogen peroxide by Mycoplasma pneumoniae $(\mathrm{mg} / \mathrm{l})$} \\
\cline { 2 - 4 } & 5 & 10 & 25 \\
\hline $24 \mathrm{hrs}$ & $20^{*}[18.5 ; 26]$ & $37[30.25 ; 45]$ & $51^{*}[48.5 ; 54.75]$ \\
\hline $48 \mathrm{hrs}$ & $31^{*}[27 ; 32.5]$ & $53[37.75 ; 62.25]$ & $84^{*}[77.75 ; 88.75]$ \\
\hline $72 \mathrm{hrs}$ & $68^{*}[67 ; 71]$ & $85[76.5 ; 90.5]$ & $96^{*}[92.25 ; 97.5]$ \\
\hline
\end{tabular}

Note: * - differences are relevant with a significance level of $\mathrm{p}<0.05$

The isolates of Mycoplasma pneumoniae producing hydrogen peroxide at a concentration of $5 \mathrm{mg} / 1$ were characterized by significantly reduced cytotoxicity (Table 2) compared to the isolates producing hydrogen peroxide at a concentration of $10 \mathrm{mg} / 1$, which was reflected in the presence of a larger number of viable cells in each time period. All the Mycoplasma pneumoniae isolates producing hydrogen peroxide at a concentration of $5 \mathrm{mg} / 1$ were carriers of the A152T nucleotide substitution, as a result of which His51, which is significant for the activity of the G3P oxidase enzyme, was substituted by Leu. The Mycoplasma pneumoniae isolates with this nucleotide substitution produced less hydrogen peroxide than the Mycoplasma pneumoniae isolates, the G3P oxidase gene of which was free of A152T nucleotide substitution, and showed reduced cytotoxicity with respect to respiratory epithelial cells. The isolates of $M y$ coplasma pneumonia producing hydrogen peroxide at a concentration of $25 \mathrm{mg} / 1$ and carrying the G163C substitution (Asp55His) showed the highest cytotoxicity: A549 cells were almost completely lysed 48 hours after their infection with Mycoplasma pneumoniae.

\section{Conclusion}

The activity of Mycoplasma pneumoniae G3P oxidase determines the manifestation of the pathogenic properties of Mycoplasma pneumoniae due to the production of hydrogen peroxide within the course of the enzyme action, hydrogen peroxide having a destructive effect on the respiratory epithelium cells. In the G3P oxidase gene of the Mycoplasma pneumoniae isolates obtained from the biological material of patients with bronchitis and pneumonia of mycoplasma etiology, A152T (His51Leu) and G163C (Asp55His) substitutions were identified. Their presence was accompanied by the variability of enzyme activity expressed in hydrogen peroxide production in different concentrations as compared to the reference strain of Mycoplasma pneumoniae, Mycoplasma pneumoniae clinical isolates without nucleotide substitutions and Mycoplasma pneumoniae clinical isolates, in which other nucleotide substitutions were detected in the G3P oxidase gene.

The isolates of Mycoplasma pneumoniae carrying the A152T substitution (His51Leu) produced hydrogen peroxide significantly below the level of production by the reference strain and showed reduced cytotoxicity in relation to the respiratory epithelial cells, while the Mycoplasma pneumoniae isolates bearing the G163C (Asp55His) were characterized by enhanced pathogenic properties, which manifested itself in increased hydrogen peroxide production and more clearly marked cytotoxicity in relation to respiratory epithelial cells. In this study, 3 out of 4 isolates of Mycoplasma pneumoniae with G163C substitution (Asp55His) were isolated from the clinical material of patients with mixed chlamydial-mycoplasma infection. It can be assumed that these isolates of Mycoplasma pneumoniae with enhanced pathogenic properties may cause the development of more severe forms of mycoplasma infection associated with infection by other microorganisms.

\section{REFERENCES}

1. Balish MF, Distelhorst SL. Potential molecular targets for narrow-spectrum agents to combat Mycoplasma pneumoniae infection and disease. Front Microbiol. 2016;7:Article 205.

2. Saraya T, Kurai D, Nakagaki K, Sasaki Y, Niwa S, Tsukagoshi H, Nunokawa H. [et al.l Novel aspects on the pathogenesis of Mycoplasma pneumoniae and therapeutic implications. Front Microbiol. 2014;5:Article 410. 
3. Hames C, Halbedel S, Hoppert M, Frey J. and Stülke J. Glycerol metabolism is important for cytotoxicity of Mycoplasma pneumoniae. $J$ Bacteriol. 2009;191(3):747-53.

4. Glinkina TV, Kostyuk SA. Biologicheskie mekhanizmy, obuslavlivayushchie uchastie Shlamydophila pneumoniae i Mycoplasma pneumoniae $\mathrm{v}$ patogeneze zabolevanii respiratornogo trakta. Novosti MedikoBiologicheskikh Nauk. 2017;16(2):88-96. (in Russ.)

5. Elkhal CK, Kean KM, Parsonage D, Maenpuen S, Chaiyen P, Claiborne A. and Karpus PA. Structure and proposed mechanism of L-a-glycerophosphate oxidase from Mycoplasma pneumoniae. FEBS Journal. 2015;282:3030-42.

6. Wang M, Wang Y, Yan Y, Zhu C, Huang L, Shao X, $\mathrm{Xu}$ J. [et al.] Clinical and laboratory profiles of refractory Mycoplasma pneumoniae in children. Int $J$ Infect Dis. 2014;29:18-23.

7. Glinkina TV. Printsipy etiologicheskoi mikrobiologicheskoi diagnostiki infektsii respiratornogo trakta, obuslovlennykh Shlamydophila pneumoniae i Mycoplasma pneumoniae, u detei i podrostkov. Meditsinskii Zhurnal. 2018;1:8-15. (in Russ.)

8. Großhennig S, Schmidl SR, Schmeisky G, Busse J. and Stülke J. Implication of glycerol and phospholipid transporters in Mycoplasma pneumoniae growth and virulence. Infect Immun. 2013;81:896-904.

9. Kostyuk SA, Rudenkova TV, Poluyan OS, Glinkina TV. Metodologiya vyyavleniya DNK vozbuditelei khlamidiino-mikoplazmennoi infektsii v mokrote. Laboratornaya Diagnostika. Vostochnaya Evropa. 2018;7(4):497-508. (in Russ.).

10. Li S, Li X, Wang Y, Yang J, Chen Z. and Shan S. Global secretome characterization of A549 human alveolar epithelial carcinoma cells during Mycoplasma pneumoniae infection. BMC Microbiol. 2014; 14:Article 27

\section{AKTEPATУPA}

1. Balish MF, Distelhorst SL. Potential molecular targets for narrow-spectrum agents to combat Myco- plasma pneumoniae infection and disease. Front Microbiol. 2016;7:Article 205.

2. Saraya T, Kurai D, Nakagaki K, Sasaki Y, Niwa S, Tsukagoshi H, Nunokawa H. [et al.] Novel aspects on the pathogenesis of Mycoplasma pneumoniae and therapeutic implications. Front Microbiol. 2014;5:Article 410.

3. Hames C, Halbedel S, Hoppert M, Frey J. and Stülke J. Glycerol metabolism is important for cytotoxicity of Mycoplasma pneumoniae. $J$ Bacteriol. 2009;191(3):747-53.

4. Гминкина ТВ, Костюк СА. Биологические механизмы, обуславливающие участие Chlamydophila pneumoniae и Mycoplasma pneumoniae в патогенезе заболеваний респираторного тракта. Новости $\mathrm{Me}$ дико-Биологических Наук. 2017;16(2):88-96.

5. Elkhal CK, Kean KM, Parsonage D, Maenpuen S, Chaiyen P, Claiborne A. and Karpus PA. Structure and proposed mechanism of L-a-glycerophosphate oxidase from Mycoplasma pneumoniae. FEBS Jour nal. 2015;282:3030-42.

6. Wang M, Wang Y, Yan Y, Zhu C, Huang L, Shao X, $\mathrm{Xu}$ J. [et al.] Clinical and laboratory profiles of refractory Mycoplasma pneumoniae in children. Int $J$ Infect Dis. 2014;29:18-23.

7. ГАинкина ТВ. Принципы этиологической микробиомогической диагностики инфекций респираторного тракта, обусловленных Chlamydophila pneumoniae и Mycoplasma pneumoniae, у детей и подростков. Медииинский Журнал. 2018;1:8-15.

8. Großhennig S, Schmidl SR, Schmeisky G, Busse J. and Stülke J. Implication of glycerol and phospholipid transporters in Mycoplasma pneumoniae growth and virulence. Infect Immun. 2013;81:896-904.

9. Костюк СА, Руденкова ТВ, Полуян ОС, Глинкина ТВ. Методомогия выявмения ДНК возбудитемей хламидийно-микоплазменной инфекции в мокроте. Аабораторная Диагностика. Восточная Eвpona. 2018;7(4):497-508.

10. Li S, Li X, Wang Y, Yang J, Chen Z. and Shan S. Global secretome characterization of A549 human alveolar epithelial carcinoma cells during Mycoplasma pneumoniae infection. BMC Microbiol. 2014;14:Article 27.
Поступила 06.03.2020

Received 06.03.2020

Принята в печать 24.06.2020

Accepted 24.06.2020

Information about authors:

Svetlana A. Kostiuk - Doctor of Medical Sciences, Professor, Chief researcher at the Science-Research Laboratory of Belarusian Medical Academy for Postgraduate Education; e-mail: s.kostiuk@mail.ru; https://orcid.org/0000-0002-3252-2626

Tatyana V. Hlinkina - Researcher at the Science-Research Laboratory of Belarusian Medical Academy for Postgraduate Education; https://orcid.org/0000-0002-3512-8499

Olga S. Poluyan - Leading researcher of the Science-Research Laboratory of Belarusian Medical Academy for Postgraduate Education; https://orcid.org/0000-0001-7130-2776

Tatyana V. Rudenkova - Candidate of Biological Sciences, Leading researcher at the Science-Research Laboratory of Belarusian Medical Academy for Postgraduate Education; https://orcid.org/0000-0002-8917-6816

Corresponding author:

Svetlana A. Kostiuk - e-mail: s.kostiuk@mail.ru

\section{Сведения об авторах:}

Костюк Светлана Андреевна - д.м.н., профессор, главный научный сотрудник Научно-исследовательской маборатории ГУО “Беморусская медицинская академия посмедипломного образования»; e-mail: s.kostiuk@mail.ru; https://orcid.org/0000-0002-3252-2626

Глинкина Татьяна Владимировна - научный сотрудник Научно-исследовательской маборатории ГУО "Белорусская медицинская академия последипломного образования"; https://orcid.org/0000-0002-3512-8499

Полуян Ольга Сергеевна - к.б.н., ведущий научный сотрудник Научно-исследовательской маборатории ГУО "Беморусская медицинская академия посмедипмомного образования"; https://orcid.org/0000-0001-7130-2776

Руденкова Татьяна Владимировна - к.б.н., ведущий научный сотрудник Научно-исследовательской маборатории ГУО «Беморусская медицинская академия последипмомного образования"; https://orcid.org/0000-0002-8917-6816

Автор, ответственный за перепнску:

Костюк Светлана Андреевна - e-mail: s.kostiuk@mail.ru 